\title{
O edukacji włączającej - z uwzględnieniem problemu bezpieczeństwa uczniów w kontekście formalnoprawnym
}

\author{
KEYWORDS \\ inclusive education, education \\ system, safety
}

\begin{abstract}
Katarzyna Jadach, O edukacji włączającej - z uwzględnieniem problemu bezpieczeństwa uczniów w kontekście formalnoprawnym [Inclusive education and the problem of safety in Polish school in formal and legal aspects]. Kultura - Społeczeństwo - Edukacja nr 2(20) 2021, Poznań 2021, pp. 123-139, Adam Mickiewicz University Press. ISSN 2300-0422, ISSN (Online) 2719-2717. DOI 10.14746/kse.2021.20.7

The key issue of this article is inclusive education in connection with the formal and legal aspects of students' safety when they are staying in educational institutions. In the first part, author describes the basic assumptions of the social model of education and it's international conditions, also referring to solutions that have been recently implemented in the Polish education system. The second part indicates the problems that may be met by educational institutions and teachers trying to achieve a state of full inclusion. They relate to the school's caring function in terms of security guarantees. The diversity of student population, especially wide range of educational needs may make it impossible for teachers to develop specific approach to individual pupil. It's caused by formal items, largely determined by the financial situation of particular local government units.
\end{abstract}

\footnotetext{
* ORCID: https://orcid.org/0000-0002-4875-6558.
} 


\section{Słowo wstępne}

Współcześnie toczący się dyskurs nad potrzebą rozwijania społecznego modelu pedagogiki specjalnej, koncentrującego się na usuwaniu barier w procesie edukacji poprzez stwarzanie warunków do konstruktywnych interakcji pomiędzy uczniem a jego otoczeniem, prowokuje do refleksji nad znaczeniem uwarunkowań normatywnych jako stanowiących element szerszego kontekstu, w jakim postulowana inkluzja ma zachodzić. Formalny aspekt podejmowanych działań edukacyjnych ma znaczenie nie tylko $\mathrm{z}$ uwagi na konieczność dostosowania się przez poszczególne podmioty edukacji, $\mathrm{w}$ tym również władze oświatowe, do porządku prawnego, $\mathrm{w}$ jakim krajowy system oświaty funkcjonuje, ale również z uwagi na zdiagnozowane na podstawie licznych badań ambiwalentne postawy nauczycieli prezentowane w obliczu przedsiębranych na rzecz edukacji włączającej działań1. Akceptacja i zaangażowanie nauczycieli ma znaczenie podstawowe dla osiągnięcia w warunkach polskiej szkoły stanu uznawanego powszechnie za pożądany - możliwie pełnej inkluzji. Rodzi się w związku z tym pytanie o zasadność obaw i wątpliwości wyrażanych przez przedstawicieli tej grupy.

$\mathrm{W}$ niniejszym opracowaniu zasygnalizowano jedną z możliwych interpretacji tego stanu, odnosząc się do wykładni przepisów prawa, zwłaszcza oświatowego w tych fragmentach, gdzie mowa jest o odpowiedzialności prawnej za ucznia.

${ }^{1}$ Z badań opublikowanych przez PFRON wynika, że „połowa przedstawicieli placówek edukacyjnych wyraża przekonanie, iż osoby niepełnosprawne powinny uczyć się w placówkach specjalnych (średnia 5,7), a co czwarty (24\%) utrzymuje, iż osoby niepełnosprawne w ogóle nie nadają się do normalnych szkół, bo nie są w stanie w nich funkcjonować (średnia 4,3). Średnio co czwarty badany (...) przedstawiciel instytucji otoczenia osób niepełnosprawnych wyraża przekonanie, iż osoby niepełnosprawne w szkole narażone są tylko na stres i nic więcej. Konsekwentnie podobny odsetek uznaje, iż w procesie edukacji powinny być one traktowane ulgowo". Zob. Pentor Research International (2009), Badania wplywu kierunku i poziomu wykształcenia na aktywność zawodowa osób niepełnosprawnych, raport końcowy, część 1 z 6, https://www.pfron.org.pl/fileadmin/files/r/7777_Raport_CZESC_1z6_final.pdf, dostęp: 15.06.2021. O zróżnicowanych, w tym również negatywnych, postawach i opiniach nauczycieli na temat procesu integracji i inkluzji edukacyjnej świadczą też wyniki badań sondażowych, przeprowadzonych na przestrzeni ostatnich kilku lat. Tytułem przykładu można wskazać: J. Bąbka, M. Podgruszewska (2016), Polityka oświatowa wobec uczniów ze specjalnymi potrzebami edukacyjnymi w perspektywie lokalnej - na podstawie opinii nauczycieli małego miasta, Niepetnosprawność. Dyskursy Pedagogiki Specjalnej, 22, s. 92-106; K. Ćwirynkało, A. Żyta (2015), Przekonania nauczycieli na temat edukacji włączającej uczniów ze specjalnymi potrzebami, Szkoła Specjalna, 4, s. 245-259; M. Uberman, A. Mach (2016), Kompetencje nauczyciela edukacji wczesnoszkolnej w szkole ogólnodostępnej w pracy z dzieckiem z niepełnosprawnością, Lubelski Rocznik Pedagogiczny, t. XXXV, z. 3, s. 165-185; H. Żuraw (2016), Wizerunek dziecka z zaburzeniami rozwoju w poglądach nauczycieli szkół masowych, Lubelski Rocznik Pedagogiczny, t. XXXV, z. 3, s. $75-105$. 
W przekrojowych badaniach nad zjawiskiem edukacji włączającej w Polsce proponowana interpretacja powinna zostać odniesiona do formalnoprawnych uwarunkowań determinujących stopień realizacji społecznego modelu edukacji.

\section{Edukacja włączająca jako koncepcja pedagogiczna}

Pojęcie "edukacja włączająca” odnosi się do faz rozwoju pedagogiki specjalnej, ewoluującej od stanu ekskluzji (wykluczenia) przez separację (oddzielenie) po integrację i inkluzję (Sipowicz, Pietras, 2017: 9)². Z uwagi na zamienne traktowanie dwóch ostatnich pojęć należy zaakcentować, że integracja stanowi koncepcję pedagogiczną zakładającą nauczanie dzieci i adolescentów z dysfunkcjami razem $\mathrm{z}$ ich rówieśnikami bez niepełnosprawności w specjalnie w tym celu stworzonych szkołach lub klasach integracyjnych. Inkluzja z kolei oznacza, iż każda placówka oświatowa przyjmuje uczniów niepełnosprawnych, co umożliwia im uczęszczanie do szkół rejonowych wspólnie z rówieśnikami. Według tej koncepcji każdemu dziecku w systemie oświaty opartym na powszechnym dostępie powinno się zapewnić spersonalizowane wsparcie w postaci indywidualnego toku nauczania w warunkach szkolnych (Sipowicz, Pietras, 2017: 11).

Charakteryzowany nurt pedagogiczny oparty jest na podbudowie aksjonormatywnej odnoszącej się do idei praw człowieka i wartości takich, jak: akceptacja i szacunek dla każdego człowieka, poszanowanie dla różnorodności, partycypacja, aktywne zaangażowanie. Z opracowań stanowiących swoiste przewodniki zawierające wskazówki w zakresie implikacji założeń edukacji włączającej wynika, że wiąże się ona m.in. z: „równym traktowaniem i obdarzaniem szacunkiem wszystkich uczniów i pracowników szkoły”; „Zwiększeniem uczestnictwa uczniów w kulturze, programie nauczania oraz społeczności szkolnej, jak również zmniejszeniem zjawiska wykluczenia w tych obszarach”; „przekształceniem kultury organizacyjnej w taki sposób, by uwzględniała ona zróżnicowanie uczniów w danej społeczności”; „Zmniejszeniem barier w procesie edukacji”; „postrzeganiem zróżnicowania uczniów jako bogactwa, zasobu wspomagającego naukę, a nie jako problemu, jaki należy rozwiązać”; „przyznaniem uczniom prawa do nauki w miejscu swojego zamieszkania”; „podkreśleniem roli szkoły w budowaniu lokalnej społeczności” i związanym z tym „propagowaniem współpracy pomiędzy szkołami i lokalnymi społecznościami” (Booth, Ainscow, 2002: 3).

2 Autorzy odwołują się do koncepcji Aloisa Bürli opisanej w książce: A. Bürli (1997), Internationale Tendenzen in der Sonderpädagogik. Vergleichende Betrachtung mit Schwerpunkt auf den europäischen Raum, Hagen. 
Pedagodzy specjalni podkreślają, że istotę zabiegów inkluzyjnych należy odnieść do konieczności rozpoznania społecznych kontekstów procesu, takich jak: bieda, marginalizacja, dziedziczenie kulturowe i ich skutków dla uczenia się i dla rozwoju (Chrzanowska, 2009: 268)33. Włączania edukacyjnego nie można postrzegać wyłącznie przez pryzmat umieszczania dzieci niepełnosprawnych w szkołach powszechnych, ale rozpatrywać ten proces $w$ kategoriach bardziej uniwersalnych, jako pracę na rzecz zmiany szkoły w kierunku bardziej optymalnego zaspokajania przez nią potrzeb wszystkich uczniów. Tak rozumiane włączanie wiąże się ściśle $\mathrm{z}$ uruchamianiem zmian systemowych $\mathrm{w}$ oświacie, a także szerzej - $\mathrm{z}$ wykorzystywaniem mechanizmów polityki społecznej. Kompleksowe wielopłaszczyznowe zmiany mają w efekcie doprowadzić do odejścia od modelu braków i deficytów w kierunku modelu społecznego, adaptacyjnego. Forsowany model zakłada opresyjny i dyskryminujący charakter działania społeczeństwa i reprezentujących go instytucji, w związku z czym główny akcent położony jest na walkę ze stereotypami i eliminowanie przeszkód, które utrudniają bądź wręcz uniemożliwiają osobom niepełnosprawnym społeczną partycypację. Dokonuje się to zarówno na drodze przekształceń w obrębie konkretnej instytucji, jak i w skali makro, tzn. w ramach zmian normatywnych i wywierania wpływu na społeczne postawy, zwłaszcza te utrwalające mechanizmy wykluczania (Chrzanowska, 2009: 268 i n.).

\section{Włączanie (inkluzja) w prawie międzynarodowym i unijnym}

Zarysowany kierunek zmian w podejściu do osób z niepełnosprawnościami i deficytami widoczny jest w opracowywanych przez światowe organizacje dokumentach prawa międzynarodowego i innych działaniach podejmowanych na skalę ponadregionalną i regionalną ( $w$ tym europejską).

W ramach formalnoprawnych uzasadnień uruchamianych na przestrzeni ostatnich lat zabiegów inkluzyjnych przywoływane są dokumenty dotyczące edukacji i praw człowieka, w szczególności: Powszechna Deklaracja Praw Człowieka (1948), Konwencja o prawach dziecka (1989), Światowa Deklaracja Edukacji dla Wszystkich (1990), Deklaracja z Salamanki - Wytyczne dla Działań w zakresie Specjalnych Potrzeb Edukacyjnych (1994), Milenijne Cele Rozwoju (2000), Konwencja o prawach osób niepełnosprawnych (2006). W ostatnim z przywołanych dokumentów (Konwencja o prawach osób niepełnosprawnych z dnia 13 grudnia 2006 r.) uznaje

\footnotetext{
${ }^{3}$ Autorka w swoich rozważaniach powołuje się na Petera Mittlera i jego tezy zawarte w książce: P. Mittler (2000), Working Towards Inclusive Education: Social Contexts, London.
} 
się prawo osób niepełnosprawnych do edukacji, którego realizacja - aby wykluczyć niebezpieczeństwo dyskryminowania - wymaga ukształtowania przez państwo systemu edukacji włączającej zorientowanej na pełen rozwój potencjału osób uczących się, zapewnienia im poczucia godności i własnej wartości, poszanowania oraz umożliwienia pełnego uczestnictwa w życiu społecznym (art. 24).

W zarysowanym kierunku uruchamiane są pod auspicjami ONZ działania służące zrównoważonemu rozwojowi. Akcentuje się w nich konieczność realizacji siedemnastu wiodących zintegrowanych celów, które mają stymulować w ciągu najbliższych piętnastu lat aktywność państw członkowskich w obszarach o krytycznym znaczeniu dla ludzkości i planety (Agenda ONZ na rzecz zrównoważonego rozwoju 2030). Zagadnieniu edukacji włączającej poświęcony jest w dokumencie odrębny punkt (cel 4), zgodnie z brzmieniem którego społeczność międzynarodowa zobowiązuje się do zapewnienia tego typu edukacji na wysokim poziomie, obejmującej kształcenie sprawiedliwe i włączające wszystkich do tego procesu, na wszystkich jego poziomach - edukacji przedszkolnej, nauki w szkole podstawowej, średniej oraz kształcenia technicznego i zawodowego.

Unia Europejska, deklarując wolę pełnienia roli prekursora we wdrażaniu agendy ONZ, wśród najważniejszych działań wskazuje włączenie celów zrównoważonego rozwoju do szeregu polityk i inicjatyw unijnych oraz przyjęcie tej idei za zasadę przewodnią wszystkich polityk Komisji Europejskiej. W obrębie wspólnoty europejskiej zakłada się przede wszystkim, iż tworzeniu spójnego społeczeństwa europejskiego służy takie kształcenie i szkolenie realizowane na wszystkich szczeblach systemów edukacyjnych w poszczególnych krajach członkowskich, które jest: po pierwsze wysokiej jakości; po drugie - sprzyja społecznemu włączaniu. Społeczne włączanie ma umożliwić osiągnięcie stanu spójności społecznej, minimalizując tym samym ryzyko pojawienia się negatywnych zjawisk typu: ksenofobia, nacjonalizm i wszelkie formy radykalizmu. Realizacji powyższego celu mają służyć zalecenia Rady Unii Europejskiej (Zalecenie Rady z dnia 22 maja 2018 r. w sprawie promowania wspólnych wartości, edukacji włączającej i europejskiego wymiaru nauczania), zgodnie z treścią których w przestrzeni europejskiej należy dążyć m.in. do wspierania bardziej włączającej edukacji. Wyznaczone zostały w tym obszarze trzy równoległe ścieżki postępowania względem wszystkich uczących się (zalecenie nr 4): zagwarantowanie dostępu do dobrej jakości edukacji od wczesnego dzieciństwa i przez całe życie; zapewnienie niezbędnego wsparcia zgodnie z konkretnymi potrzebami (w tym zwłaszcza w związku z trudną sytuacją społeczno-ekonomiczną, migracyjną, posiadaniem specjalnych potrzeb edukacyjnych czy szczególnych uzdolnień); ułatwienie przechodzenia między różnymi ścieżkami i poziomami edukacji oraz umożliwienie świadczenia odpowiedniego doradztwa edukacyjnego i poradnictwa zawodowego. 
W ogólnoświatowej debacie, ale również w wypowiedziach polskich badaczy rzeczywistości edukacyjnej wybrzmiewają przede wszystkim pozytywne efekty procesu integracji i włączania, zarówno na poziomie indywidualnym, instytucjonalnym, jak i społecznym ${ }^{4}$. Wśród zalet inkluzji dokonywanej w sferze edukacji wymienia się zwłaszcza zrównanie praw osób niepełnosprawnych i przeciwdziałanie ich dyskryminacji, w tym zapewnienie równego dostępu do edukacji jako fundamentalnego czynnika wyrównującego szanse na pełny udział w życiu społecznym, na zasadzie równości z innymi osobami (Czarnocka, 2018: 15).

Powszechne afirmatywne podejście do polityki włączania sprawia, iż pod auspicjami ONZ oraz Unii Europejskiej i jej poszczególnych agend podejmowane są zaawansowane działania mające maksymalnie zbliżyć nas do - uważanego za najbardziej optymalny i zgodny z filozofią praw człowieka - stanu pełnej inkluzji ${ }^{5}$.

\section{Polska polityka oświatowa a edukacja włączająca}

W inicjowanych w Polsce po 1989 r. w ramach polityki oświatowej działaniach widoczny jest wzgląd na opisany wyżej kierunek postępowania z osobami o specjalnych potrzebach edukacyjnych ( $w$ tym również uczniów niepełnosprawnych) w jednostkach systemu oświaty. Poprzez wprowadzanie konkretnych rozwiązań normatywnych ${ }^{6}$, organizacyjnych i finansowych ${ }^{7}$ podejmowane są wysiłki na rzecz

${ }^{4}$ Zob. m.in. opracowania: G. Szumski (2009), Integracyjne kształcenie niepetnosprawnych: sens i granice zmiany edukacyjnej, Warszawa; G. Szumski, A. Firkowska-Mankiewicz (2010), Wokół edukacji włączającej: efekty kształcenia uczniów z niepetnosprawnościa intelektualna w stopniu lekkim w klasach specjalnych, integracyjnych i ogólnodostępnych, Warszawa; G. Szumski (2014), Edukacja włączająca - niedokończony projekt, Ruch Pedagogiczny, 4, s. 127-140.

${ }^{5} \mathrm{Z}$ danych zbieranych przez Europejską Agencję ds. Specjalnych Potrzeb i Edukacji wynika, iż w Europie istnieje szeroki wachlarz podejść w zakresie polityki i świadczeń edukacyjnych stosowanych w poszczególnych krajach pod adresem uczniów posiadających oficjalną decyzję o SPE. Zakres umieszczania takich uczniów w odrębnych placówkach włączających jest zróżnicowany, jednak we wszystkich krajach istnieją uczniowie, których prawo do kształcenia w placówkach realizujących edukację włączającą wraz z rówieśnikami nie jest w pełni przestrzegane. Europejska Statystyka Edukacji Włączajacej. Główne przesłania i wnioski (2014/2016), https://www.european-agency.org/sites/ default/files/easie_key_messages_and_findings_2014-2016_pl_0.pdf, dostęp: 26.05.2021.

${ }^{6}$ Problematyka integracji i inkluzji podejmowana jest $\mathrm{w}$ aktach normatywnych rangi ustawowej (Ustawa z dnia 14 grudnia 2016 r. Prawo oświatowe), jak i wykonawczej (rozliczne rozporządzenia wydawane przez MEN, których katalog można znaleźć na stronie internetowej ministerstwa. Zob. https://www.gov.pl/web/edukacja-i-nauka).

7 Chodzi zwłaszcza o wzrost środków finansowych przeznaczanych w ramach subwencji oświatowej na kształcenie uczniów z dysfunkcjami oraz nałożenie na jednostki samorządu terytorialnego obowiązku przeznaczania $\mathrm{w}$ danym roku budżetowym na realizację zadań wymagających stosowania specjalnej organizacji nauki i metod pracy dla dzieci i młodzieży ze specjalnymi potrzebami 
implikacji wytycznych, zaleceń, reguł i celów, które forsowane są przez organizacje światowe i regionalne. W związku z tym, iż z treści międzynarodowych dokumentów, jak również z rekomendacji opracowywanych przez środowiska osób niepełnosprawnych wynika jednoznaczny zakaz dyskryminacji, uruchomiony został w naszym kraju proces włączania przedstawicieli tej bardzo zróżnicowanej grupy w kształcenie na wszystkich etapach powszechnego systemu edukacji.

Aktualnie w polskich przepisach oświatowych gwarantowane jest pełne poszanowanie praw osób niepełnosprawnych w edukacji. System oświaty powinien zapewnić, między innymi, możliwość pobierania nauki we wszystkich typach szkół przez dzieci i młodzież niepełnosprawną, niedostosowaną społecznie i zagrożoną niedostosowaniem społecznym - zgodnie z indywidualnymi potrzebami rozwojowymi i edukacyjnymi oraz predyspozycjami; opiekę nad uczniami niepełnosprawnymi - przez umożliwianie realizowania zindywidualizowanego procesu kształcenia, form i programów nauczania oraz zajęć rewalidacyjnych (art. 1 Ustawy z dnia 14 grudnia 2016 r. Prawo oświatowe). Przewidziane w przepisach prawnych poświęconych pomocy psychologiczno-pedagogicznej gwarancje wiążą się z intensywną pracą na rzecz organizowania kształcenia, wychowania i opieki dla uczniów niepełnosprawnych w przedszkolach, oddziałach przedszkolnych w szkołach podstawowych, innych formach wychowania przedszkolnego, szkołach i oddziałach w integracji z uczniami pełnosprawnymi w przedszkolu, oddziale przedszkolnym w szkole podstawowej, innej formie wychowania przedszkolnego lub szkole, najbliższych miejsca zamieszkania ucznia niepełnosprawnego ( $\$ 2$ ust. 2 Rozporządzenia MEN z dnia 9 sierpnia 2017 r. w sprawie warunków organizowania kształcenia, wychowania i opieki dla dzieci i młodzieży niepełnosprawnych, niedostosowanych społecznie i zagrożonych niedostosowaniem społecznym).

Zgodnie z informacjami publikowanymi na stronie internetowej Ministerstwa Edukacji i Nauki w polskim systemie oświaty uruchamianych jest szereg możliwości realizacji zróżnicowanych potrzeb edukacyjnych dzieci i młodzieży, w tym dzieci i młodzieży z niepełnosprawnościami. Wśród podstawowych form wymienić można: wczesne wspomaganie rozwoju dzieci; zróżnicowane formy pomocy psychologiczno-pedagogicznej (obejmujące zwłaszcza: pomoc w trakcie bieżącej pracy, zajęcia dydaktyczno-wyrównawcze, zajęcia rozwijające umiejętności uczenia się, zajęcia specjalistyczne, zindywidualizowaną ścieżkę kształcenia, klasy terapeu-

edukacyjnymi środków w wysokości nie mniejszej niż wynikająca z podziału przeznaczanej na ten cel części oświatowej subwencji ogólnej dla jednostek samorządu terytorialnego w danym roku kalendarzowym. Kwestię tę regulują przepisy wykonawcze wydawane corocznie przez MEN (rozporządzenie w sprawie sposobu podziału części oświatowej subwencji ogólnej dla jednostek samorządu terytorialnego). 
tyczne, warsztaty, porady i konsultacje); dostosowanie czasu rozpoczęcia kształcenia oraz okresu jego trwania (wcześniejsze rozpoczęcie lub odroczenie realizacji obowiązku szkolnego, przedłużanie etapów edukacyjnych dla uczniów niepełnosprawnych, skracanie okresu kształcenia dla uczniów niedostosowanych społecznie i zagrożonych niedostosowaniem społecznym, promocja do klasy programowo wyższej w trakcie roku szkolnego, indywidualny tok nauki); dostosowanie warunków i formy egzaminów zewnętrznych (MEN 2020, Edukacja włączająca - dotychczasowe i planowane działania MEN). Do ważnych przedsięwzięć legislacyjnych uruchamianych w ostatnich latach zaliczyć można: oparcie kształcenia uczniów ze specjalnymi potrzebami edukacyjnymi na założeniach diagnozy funkcjonalnej; zmianę zasad organizacji nauczania indywidualnego; stworzenie nowej formy pomocy psychologiczno-pedagogicznej w postaci zindywidualizowanej ścieżki kształcenia czy uruchomienie kształcenia nauczycieli w kierunku specjalności terapia pedagogiczna.

Z publikowanych corocznie przez GUS danych dotyczących stanu polskiej oświaty, jak również tych gromadzonych w systemie SIO wynika wzrastający wskaźnik liczby uczniów ( $w$ różnym wieku i z różnym rodzajem niepełnosprawności) funkcjonujących w integracyjnych i ogólnodostępnych formach edukacji. Szkolnictwo otwarte staje się coraz powszechniejszą formą kształcenia uczniów ze specjalnymi potrzebami edukacyjnymi, co świadczy o faktycznym dokonaniu się na przestrzeni trzydziestu lat zmian w systemie. Opierając się na opracowaniach z zakresu pedagogiki specjalnej, można wskazać na następujące kierunki: od integracji ukrytej poprzez możliwość w latach 1991-1993 do prawa wspólnej nauki w 1999 r.; od ignorowania potrzeb edukacyjnych uczniów niepełnosprawnych w integracji ukrytej do obowiązku ich zaspokajania; od placówek wczesnej diagnozy i wspierania rozwoju dzieci niepełnosprawnych do rozwoju do programu wczesnego wspierania rozwoju dla wszystkich dzieci z orzeczeniem o niepełnosprawności lub zagrożonych niepełnosprawnością; od administracyjnych decyzji o drodze edukacji opartej na rodzaju i stopniu niepełnosprawności do możliwości wyboru środowiska edukacyjnego przez ucznia lub jego prawnych opiekunów; od określeń dyskryminujących (uczeń niepełnosprawny) do niedyskryminujących (uczeń ze specjalnymi potrzebami edukacyjnymi) (Dryżałowska, 2017: 38).

\section{Edukacja włączająca a bezpieczeństwo uczniów - ujęcie kryłyczne}

Wdrażaniu założeń pedagogiki inkluzyjnej do krajowego systemu oświaty powinna towarzyszyć pamięć, iż wymaga to podejścia systemowego. Skuteczność tak 
ukierunkowanych inicjatyw uzależniona jest od spełnienia szeregu postulatów, wśród których wymieniane są zwłaszcza: polityczna zgoda w zakresie realizacji europejskich celów; uruchamianie spójnych rozwiązań służących przygotowaniu wszystkich placówek oświatowych do przyjmowania dzieci o różnym stanie zdrowia i ze zróżnicowanymi potrzebami edukacyjnymi, z czym wiąże się w szczególności doskonalenie zawodowe nauczycieli, tworzenie dla nich metodycznego i psychologicznego zaplecza, jak i wypracowywanie bardziej elastycznych podstaw programowych, umożliwiających indywidualną pracę z uczniem; gwarantowanie na poziomie państwowym środków finansowych umożliwiających stworzenie dydaktycznego, organizacyjnego oraz kadrowego zaplecza; rozwijanie współpracy szkoły ze środowiskiem społecznym, w tym również organizacjami pozarządowymi. Na stopień zaawansowania wdrażanych gwarancji wynikających z założeń polityki włączającej wpływ ma więc wiele czynników, wśród których akcentuje się zwłaszcza przemiany społeczne w obszarze postrzegania osób niepełnosprawnych. Swoją wagę mają jednak również uwarunkowania formalne.

Poniżej podjęto wątek rozważań nad tym aspektem formalnoprawnym zjawiska inkluzji, który dotyczy bezpieczeństwa dzieci i uczniów przebywających na terenie placówki oświatowej. Inspirację do rozważań stanowią wypowiedzi i badania przeprowadzane przez autorów zajmujących się procesem inkluzji, którzy problematykę bezpieczeństwa odnoszą do animowania rodzimego kapitału społecznego i kształtowania klimatu szkoły bądź klasy, opierając go na pozytywnych relacjach między członkami szkolnej społeczności ${ }^{8}$. Uznając fundamentalne znaczenie pracy wychowawczej ukierunkowanej na tworzenie i rozwijanie więzi między uczniami (praca nad relacjami), co umożliwia powstanie realnej wspólnoty i gwarantuje skuteczną profilaktykę, należy mieć na uwadze podstawowy aspekt działalności opiekuńczej placówki oświatowej, jakim jest zapewnienie dziecku bezpieczeństwa.

Implikacja poszczególnych założeń edukacji włączającej może budzić obawy o realizację ustawowych gwarancji w tym obszarze. Dotyczy to zwłaszcza dzia-

${ }^{8}$ Przykładowo w badaniach przeprowadzonych z udziałem matek dzieci z zespołem Downa, wśród wyznaczników dobrej jakości kształcenia, obok takich czynników jak: merytoryczne przygotowanie nauczyciela-wychowawcy do pracy z takim uczniem, cechy osobowościowe nauczyciela-wychowawcy i uwarunkowania materialne, wskazywano na dobrą integrację grupy, akcentując konieczność dbania o pozytywne relacje między rówieśnikami w grupie i budowanie klimatu bezpieczeństwa. Zob. K. Ćwirynkało, A. Żyta (2014), Dlaczego edukacja włączająca nie zawsze jest najlepszym rozwiązaniem? Doświadczenia i plany edukacyjne wobec dzieci z zespołem Downa w relacjach matek, Szkoła Specjalna, 3, s. 186-201. Na temat wpływu czynników kulturowych na rozwój edukacji włączającej i ich znaczenia w kreowaniu pozytywnych zachowań i postaw wobec uczniów niepełnosprawnych zob. Z. Janiszewska-Nieścioruk (2019), O ciągle nierozwiązanych problemach ogólnodostępnej edukacji utrudniających proces inkluzji uczniów/osób niepełnosprawnych, Niepetnosprawność. Dyskursy Pedagogiki Specjalnej, 33, s. 71-82. 
łań edukacyjnych ukierunkowanych na zagospodarowanie czasu pobytu dziecka w szkole. Z wypowiedzi zwolenników edukacji inkluzyjnej wybrzmiewa przekonanie o konieczności takiego aranżowania przestrzeni edukacyjnej, w której: uczniowie mogą swobodnie, zgodnie ze swoimi potrzebami i zainteresowaniami spędzać przerwy między lekcjami, korzystając dowolnie z dostępnych urządzeń i sprzętu sportowego i rekreacyjnego; uczniowie korzystają z przerw relaksacyjnych $w$ trakcie lekcji, zażywając ruchu na świeżym powietrzu; $w$ toku nauczania korzysta się z odmiennych lokalizacji w przestrzeni szkolnej, co wiąże się z częstym przemieszczaniem się grupy; uczeń preferujący naukę poza klasą wybiera miejsce odosobnione, w którym może się wyciszyć i uczyć w samotności; rezygnuje się z upominania uczniów i ich karcenia (co oznacza m.in. świadomą rezygnację ze wskazywania błędów, z przerywania uczniowi w sytuacji, gdy mówi nie na temat, traktowania jako ostateczności zwrócenia przez nauczyciela uczniowi uwagi na niestosowne zachowanie) (Sipowicz, Pietras, 2017: 33-44). Forsowane oczekiwanie rezygnacji przez nauczycieli z dominującej pozycji prowadzącego zajęcia i jego wejście w skład tzw. teamu, w którym jako członek prowadzi wyłącznie dialog z uczniami, rodzi pytanie o jego rolę jako głównego opiekuna. Czy również ten aspekt nauczycielskiej profesji ulega modyfikacji?

Mając na uwadze ustawową rangę regulacji dotyczących kwestii bezpieczeństwa, należy stwierdzić, iż nauczyciel pracujący w warunkach szkoły inkluzyjnej pozostaje podmiotem $\mathrm{w}$ pełni odpowiedzialnym za swoich wychowanków i przyjęta na gruncie dokumentów międzynarodowych koncepcja pedagogiczna tej odpowiedzialności nie modyfikuje ani nie uchyla. Warto ją więc w obecnym dyskursie nad stanem i optymalnymi warunkami bardziej konsekwentnego implementowania założeń edukacji włączającej w Polsce przywołać. Uzasadnieniem dla rozwinięcia tego wątku są ponadto wyniki badań nad zjawiskiem przemocy w szkole, z których wyłania się profil ofiary dręczenia mającej wiele cech, które można odnieść do uczniów ze specjalnymi potrzebami edukacyjnymi, zwłaszcza niepełnosprawnych intelektualnie (Janiszewska-Nieścioruk, 2016: 109). Równolegle pamiętać należy, iż w grupie uczniów uczęszczających do szkół ogólnodostępnych, a posiadających orzeczenie o potrzebie kształcenia specjalnego znajdują się dzieci z zaburzeniami zachowania, wykazujące postawy agresywne i autoagresywne, wymagające pracy w małych grupach terapeutycznych (Dobrzyńska, 2021). Ich niedostosowanie do dyscypliny szkolnej i zasad współżycia społecznego może stanowić wyzwanie, któremu nauczyciel, często pozbawiony wsparcia nauczyciela wspomagającego i psychologa szkolnego, pracujący z grupą liczącą co najmniej kilkanaście osób (dodajmy - z różnymi potrzebami edukacyjnymi), nie będzie w stanie sprostać. 


\section{Odpowiedzialność szkoły za bezpieczeństwo uczniów jako zadanie podstawowe}

Zapewnienie uczniowi bezpieczeństwa stanowi zadanie opiekuńcze, z którego realizacją wiąże się aktywność szeregu podmiotów: organu prowadzącego, organu nadzoru pedagogicznego, poszczególnych organów placówki (dyrektora, rady pedagogicznej, rady rodziców, rady szkoły) oraz konkretnych nauczycieli. Pomijając wątek rozważań bardziej szczegółowych ${ }^{9}$ w kontekście wdrażania na grunt polskiej szkoły założeń edukacji włączającej, warto przywołać podstawowe charakterystyki kategorii odpowiedzialności prawnej związanej z bezpieczeństwem uczniów przebywających na terenie placówki oświatowej i biorących udział w zajęciach organizowanych przez tę placówkę.

1. W przypadku pieczy nad dziećmi sprawowanej w warunkach placówki oświatowej zarówno doktryna prawnicza, jak i judykatura konsekwentnie opowiadają się za szeroką koncepcją nadzoru, tzn. taką, która obejmuje zarówno zapewnienie odpowiedniej opieki nad uczniami, jak i dbałość o warunki ogólnego bezpieczeństwa na terenie szkoły i właściwą organizację pracy ${ }^{10}$. Odpowiedzialność ta wynika z faktu wykonywania przez organy oświatowe władzy publicznej oraz posługiwania się przez placówki oświatowe jako zakłady administracyjne aktami władczymi, co wiąże się z koniecznością podporządkowania się im przez ucznia ${ }^{11}$.

${ }^{9} \mathrm{~W}$ temacie bezpieczeństwa autorka wypowiedziała się w następujących publikacjach: K. Jadach (2017), Odpowiedzialność prawna nauczycieli za bezpieczeństwo ucznia w placówce oświatowej - zarys problemu, Studia Prawnicze i Administracyjne, 2, s. 11-18; K. Jadach (2020), Dyrektor szkoły w roli pracodawcy - przegląd wybranych zagadnień funkcjonowania szkoły jako zakładu pracy, Studia Edukacyjne, 57, s. 119-144; K. Jadach, (2020), Oświatowe konteksty wykonywania pieczy nad małoletnim, [w:] M. Łączkowska-Porawska (red.), Dziecko - rodzice - państwo w kontekście świadczeń zdrowotnych, edukacyjnych i przemocy domowej, Warszawa.

${ }^{10} \mathrm{~W}$ doktrynie prawniczej funkcjonują dwie koncepcje definiowania nadzoru. W ujęciu wąskim nadzór stanowi wyłącznie element sprawowania przez rodziców/opiekunów/wychowawców pieczy nad osobą małoletnią. Definiowany jest on wówczas, przykładowo, jako czuwanie (baczenie) nad osobą nadzorowaną oraz podejmowanie interwencji mającej na celu zapobieżenie szkodzie („nadzorowanie trybu życia”). W ujęciu szerokim nie jest możliwie całkowite rozdzielenie znaczeń takich pojęć, jak: wychowanie, kierowanie, nadzór, co w konsekwencji sprawia, że w zasadzie każda czynność nadzoru nad dzieckiem jest zarazem działaniem wychowawczym. Zob. m.in.: T. Sokołowski (1987), Władza rodzicielska nad dorastającym dzieckiem, Poznań, s. 32-33, 181; J. Słyk (2011), Odpowiedzialność cywilna rodziców za szkodę wyrządzona przez ich dziecko a sposób i zakres wykonywania przez nich władzy rodzicielskiej, Warszawa, s. 179. Podobnie: J. Winiarz (1973), Odpowiedzialność cywilna z tytułu nadzoru nad dzieckiem, Warszawa, s. 1 i 21.

${ }^{11}$ Zastosowanie w tego typu przypadkach mają art. 417 Kodeksu cywilnego oraz art. 77 Konstytucji RP, analizowane przez autorkę w rozdziale pt. Oświatowe konteksty wykonywania pieczy nad małoletnim, [w:] M. Łączkowska-Porawska (red.), Dziecko - rodzice - państwo w kontekście świadczeń zdrowotnych, edukacyjnych i przemocy domowej, Warszawa. 
Ustalenie bezprawności działania organu oświatowego oraz poniesionej przez dziecko (ucznia) szkody będącej w związku przyczynowym z tymże działaniem uruchamia odpowiedzialność organu prowadzącego placówkę, co w przypadku sektora publicznego oznacza konsekwencje finansowe dla jednostki samorządu terytorialnego lub Skarbu Państwa (art. 10 ust. 1 ustawy Prawo oświatowe w zw. $\mathrm{z}$ art. 417 Kodeksu cywilnego). Z kolei w przypadku zdarzeń, jakie miały miejsce w okolicznościach funkcjonowania szkoły i podejmowania przez nią aktów o charakterze niewładczym w grę wchodzi kilka podstaw prawnych ${ }^{12}$. Obowiązki placówki oświatowej sprowadzić można do ogólnej kategorii jakościowej, jaką jest staranność „należyta”, czyli wymagana w danych okolicznościach (np. dotyczących wieku osoby nadzorowanej, stopnia rozwoju, stanu zdrowia, osobowości, sytuacji, w której nadzór jest sprawowany, czy rodzaju zagrożeń) i stosunkach danego rodzaju, co dokumentuje bogate orzecznictwo sądów powszechnych w sprawach cywilnych, gdzie podmiotem pozywanym jest organ prowadzący placówkę oświatową.

2. Rola dyrektora w sprawowaniu właściwego nadzoru nad dziećmi wynika z powierzonego mu ogólnego obowiązku „wykonywania zadań związanych z zapewnieniem bezpieczeństwa uczniom i nauczycielom w czasie zajęć organizowanych przez szkołę lub placówkę" (art. 68 ust. 1 pkt 6 Ustawy z dnia 14 grudnia 2016 r. Prawo Oświatowe). Oznacza to jego zaangażowanie w „sprawowanie opieki nad uczniami oraz stwarzanie warunków harmonijnego rozwoju psychofizycznego poprzez aktywne działania prozdrowotne" (art. 68 ust. 1 pkt 3 Ustawy z dnia 14 grudnia 2016 r. Prawo Oświatowe), co realizowane jest w ramach działań faktycznych, jak np. dokonywanie okresowych kontroli obiektów i urządzeń szkolnych, oraz działań formalnych, np. w postaci opracowywania regulaminu porządkowego placówki.

Istnienie $\mathrm{i}$ treść tego dokumentu wiąże się z zadaniem nadzorowania całokształtu działalności kierowanej przez dyrektora placówki, pracy podległego personelu pedagogicznego, administracyjnego oraz technicznego. Ustalenia zawarte w regulaminie odnoszą się do specyfiki organizacji szkoły i dotyczą zwłaszcza: organizacji pracy (w tym zależności między pracownikami w procesie pracy); warunków przebywania na terenie zakładu pracy w czasie pracy i po jej zakończeniu; czy obowiązków pracowników dotyczących bezpieczeństwa i higieny pracy oraz ochrony przeciwpożarowej (Jadach, 2020: 137-138). Dyrektor może wprowadzić

${ }^{12} \mathrm{~W}$ przypadku szkody powstałej w efekcie niewłaściwie wykonywanego nadzoru odpowiedzialność organu prowadzącego placówkę powinna być rozstrzygana na podstawie art. 427 Kodeksu cywilnego; natomiast jeśli szkoda wynika z innych zaniedbań odpowiedzialność opiera się na ogólnych podstawach prawnych (zwłaszcza art. 415, 416, 429, 430 Kodeksu cywilnego). 
do regulaminu pracy szereg innych regulacji, które, z jego punktu widzenia, są istotne dla skutecznej realizacji zadań powierzonych placówce oświatowej, w tym również opiekuńczych. Istotnym elementem tego obszaru aktywności jest polityka kadrowa, polegająca na zatrudnianiu odpowiedniej liczby osób o stosownych kwalifikacjach, co jednak podlega znacznym ograniczeniom związanym z treścią zatwierdzanego przez organ prowadzący arkusza organizacyjnego. W związku z zapewnieniem stanu bezpieczeństwa dyrektor podlega ocenie dokonywanej przez organ nadzoru pedagogicznego, jak i przez organ prowadzący.

3. Trzecim podmiotem, do którego odnoszą się przepisy regulujące bezpieczny pobyt dzieci (uczniów) na terenie placówki oświatowej, są nauczyciele. Konkretne czynności opiekuńcze podejmowane w celu ochrony zdrowia i bezpieczeństwa dzieci (uczniów) wskazane są w poszczególnych przepisach oświatowych i akcentują niedopuszczalność pozostawiania dzieci bez opieki (przepisy mówią o nadzorze upoważnionej osoby) nie tylko na jakichkolwiek zajęciach organizowanych przez szkołę (placówkę), ale również w trakcie przerw międzylekcyjnych ( $\$ 13$ i 14 Rozporządzenia MENiS z dnia 31 grudnia 2002 r. w sprawie bezpieczeństwa i higieny w publicznych i niepublicznych szkołach i placówkach). Skuteczne pełnienie nadzoru umożliwia mu instytucja władztwa zakładowego placówki, która oznacza podległość użytkownika zakładu administracyjnego aktom i poleceniom organów tegoż zakładu (Pilich, 2015: 716). Nauczyciel jako podmiot tego władztwa może oczekiwać od ucznia dyspozycyjności w zakresie nauczania i wychowania (Homplewicz, 1983: 134), co wyraża się m.in. w ww. podporządkowaniu poleceniom, podleganiu procedurze oceniania, klasyfikowania i promowania, podleganiu dyscyplinie i posłuchu, odnoszeniu się do nauczyciela z należytym szacunkiem.

Posiadanie pedagogicznych prerogatyw przybliża omawianą grupę do rodziców wykonujących władzę rodzicielską nad swoimi dziećmi. Wynika to z faktu, iż nauczyciele stanowią wiodącą, po rodzicach, kategorię osób zobowiązanych do nadzoru nad małoletnimi. Posiadane przez nich kwalifikacje pedagogiczne i doświadczenie oraz oparcie katalogu nauczycielskich obowiązków na formule dobra ucznia sprawiają, że w orzecznictwie sądowym podkreśla się priorytetowy charakteru podejmowanych przez tę grupę działań nadzorczych ${ }^{13}$. Wywiązywanie się przez nauczyciela z zadań opiekuńczych stanowi przedmiot oceny podejmowanej

${ }^{13}$ Zdaniem Sądu Najwyższego, „w sytuacji, gdy zachowanie uczniów narusza obowiązujące zasady - lub stwarza niebezpieczeństwo ich naruszenia - nauczyciel sprawujący nadzór nad powierzonymi mu uczniami, winien w razie kolizji ciążących na nim w tym samym czasie zadań typu nadzorczego z zadaniami typu administracyjnego, dawać pierwszeństwo zadaniom nadzorczym dopóki nie zapewni warunków zapobiegających naruszeniu dyscypliny przez uczniów, mogącemu wywołać szkodę"; wyrok Sądu Najwyższego z dnia 05.05.1975 r., sygn. akt. II CR 153/75, Lex 7699. 
w procedurach regulujących różne rodzaje jego odpowiedzialności. Wśród nich wymienić należy: postępowanie dotyczące oceny pracy nauczyciela na podstawie przepisów oświatowych (tzw. odpowiedzialność merytoryczna), odpowiedzialność karną, odpowiedzialność pracowniczą oraz odpowiedzialność dyscyplinarną (Jadach, 2017: 13).

Mnogość normatywnych regulacji, jakie w przypadku zagrożenia bezpieczeństwa ucznia należy uwzględnić, stanowi swoistą specyfikę porządku formalnego, na jakim opiera się polski system oświaty i sprawia, że wyartykułowany w poszczególnych przepisach oświatowych obowiązek dbania o bezpieczeństwo przebywających na terenie szkoły dzieci (wraz z obowiązkami szczegółowymi dotyczącymi m.in. odbywania przerw, prowadzenia lekcji przez upoważnioną osobę, udzielania pierwszej pomocy, informowania dyrektora o sytuacjach niebezpiecznych) nabiera priorytetowego znaczenia. Pojawia się $\mathrm{w}$ związku $\mathrm{z}$ tym pytanie, czy w warunkach edukacji włączającej możliwe jest wypełnienie standardów bezpieczeństwa, jakie na placówki oświatowe i poszczególnych jej pracowników nakładają przepisy prawa?

Odpowiedź na powyższe pytanie wymaga uwzględnienia okoliczności funkcjonowania polskiej szkoły publicznej, z jej zróżnicowaniem w zakresie zaplecza lokalowego, dydaktycznego i kadrowego, determinowanym w znacznym stopniu nie wysokością subwencji oświatowej, a dochodami poszczególnych jednostek samorządu terytorialnego. Realizacja zasady niedyskryminacji, formułowanej przez zwolenników edukacji włączającej, aby nie odbywała się kosztem stanu bezpieczeństwa dziecka, wymagałaby zrównania wydatków przeznaczanych na edukację uczniów, czyli całkowitego uniezależnienia ich od stanu zamożności poszczególnej gminy czy powiatu. Zmiany podążające w tym kierunku zachwiałyby dotychczasową konstrukcją polskiego systemu oświatowego, opartego na modelu quasi zdecentralizowanym, finansowego na poziomie kilkudziesięciu procent ze środków samorządowych, jednak w znacznym stopniu implikującego założenia polityki oświatowej prowadzonej przez władzę państwową.

\section{Zakończenie}

Międzynarodowe wysiłki ukierunkowane na wdrażanie założeń edukacji włączającej wpisują się w nurt idei społecznej określanej mianem zrównoważonego rozwoju. Edukację tego typu uznaje się za uskuteczniającą założenia filozofii trwania i kształtowania ścisłego związku człowieka ze światem, który go otacza (Mendel, Dymnicka, Rozmarynowska, Sagan, Zielka, Puchowska, 2008: 87). Do- 
konuje się to w ramach zmiany społecznej i kulturowej „rozsiewanej” w formalnym procesie kształcenia i wychowania, a więc przy wykorzystaniu potencjału formacyjnego poszczególnych jednostek systemu oświaty na różnych etapach uczenia. Takie intencje przywoływane są $\mathrm{w}$ ramach podejmowanych $\mathrm{w}$ skali międzynarodowej działań normatywnych i aktywności w obrębie kształtowanych polityk. Wyznaczają one $\mathrm{w}$ obszarze postępowania $\mathrm{z}$ osobami niepełnosprawnymi i z dysfunkcjami kierunek włączania w powszechny system oświaty wszystkich uczniów, niezależnie od ich stanu zdrowia, co w konsekwencji ma doprowadzić do stanu pełnej społecznej integracji. Dotychczasowym sposobom postępowania $\mathrm{z}$ jednostkami słabszymi zarzuca się nadmierną segregacyjność i dyskryminowanie, co prowadzi do naruszeń podstawowych praw i wolności człowieka. Tak funkcjonujące instytucje, również placówki oświatowe, postrzegane są jako miejsca dyskryminacji instytucjonalnej przyczyniające się do tworzenia czy też konstruowania niepełnosprawności.

Współczesny nurt pedagogiki specjalnej stanowi ogromne wyzwanie dla państwa, społeczeństwa, jak i poszczególnych podmiotów edukacji. Przyczyną trudności w zakresie implikacji poszczególnych założeń edukacji włączającej mogą być czynniki formalne, związane z powierzeniem szkole na mocy przepisów rangi ustawowej i wykonawczej, obowiązku sprawowania nadzoru ujmowanego szeroko, wpisującego się w samą istotę działalności wychowawczej. Wykładnia przepisów prawa wskazuje na rygoryzm w przypisywaniu placówce oświatowej odpowiedzialności za bezpieczeństwo uczniów, co wiąże się, z jednej strony, z koniecznością podejmowania odpowiednich działań organizacyjnych, zabezpieczających i kontrolnych przez dyrektora, $z$ drugiej - sprawowania ścisłego nauczycielskiego nadzoru. Obejmuje on nie tylko obowiązek przestrzegania przepisów dotyczących bezpieczeństwa, ale również aktywności w postaci podejmowania działań realizujących zasady ostrożności i bezpieczeństwa, w tym stanowczości przy wyborze środków reakcji na niewłaściwe zachowania.

Taki normatywny fundament realizowanej przez jednostki oświatowe funkcji opiekuńczej zdaje się stać w opozycji do założeń edukacji włączającej, opartych na metodzie pracy $\mathrm{w}$ formule teamu bez wiodącej roli nauczyciela, pozbawieniu go atrybutu wychowawczego karcenia czy dążeniu do osiągnięcia stanu maksymalnego stopnia heterogeniczności grupy, co oznacza konieczność równoległego reagowania nauczyciela na bardzo zróżnicowane potrzeby. Jedynym możliwym podejściem umożliwiającym uwzględnienie przynajmniej niektórych postulatów obranego przez społeczność międzynarodową nurtu byłaby zmiana systemowa (forsowana de facto przez samych zwolenników koncepcji), obejmująca obszar zarządzania i finansowania publicznych placówek oświatowych. 


\section{Bibliografia}

Agenda ONZ na rzecz zrównoważonego rozwoju 2030, https://sdgs.un.org/2030agenda, dostęp: 14.06.2020.

Booth T., Ainscow M., (2002), Przewodnik po edukacji włączającej. Rozwój kształcenia i uczestnictwa w życiu szkoły, w polskiej adaptacji autorstwa D. Wiszejko-Wierzbickiej, A. Białek, K. Sijko, Warszawa: Olimpiady Specjalne Polska, http://www.olimpiadyspecjalne.pl/edukacja-wlaczajaca, dostęp: 16.06.2021.

Chrzanowska I. (2009), Zaniedbane obszary edukacji - pomiędzy pedagogika a pedagogika specjalną. Wybrane zagadnienia, Kraków.

Czarnocka M. (2018), Działania poradni psychologiczno-pedagogicznych w zakresie edukacji właczającej. Organizacja pomocy psychologiczno-pedagogicznej w szkołach i placówkach ogólnodostępnych, Warszawa, https://www.ore.edu.pl/2015/03/edukacja-wlaczajaca, dostęp: 10.06.2021.

Ćwirynkało K., Żyta A. (2014), Dlaczego edukacja włączająca nie zawsze jest najlepszym rozwiązaniem? Doświadczenia i plany edukacyjne wobec dzieci z zespołem Downa w relacjach matek, Szkoła Specjalna, 3, s. 186-201.

Dobrzyńska J. (2021), Edukacja włączająca jako nowa ideologia, Nasz Dziennik, 16 marca, https:// wp.naszdziennik.pl/2021-03-16/349814,edukacja-wlaczajaca-jako-nowa-ideologia.html?d=1, dostęp: 24.03.2021.

Dryżałowska G. (2017), Integracja edukacyjna z innej perspektywy, Interdyscyplinarne Konteksty Pedagogiki Specjalnej, 16, s. 33-61.

Europejska Statystyka Edukacji Włączającej. Główne przesłania i wnioski (2014/2016), https://www. european-agency.org/sites/default/files/easie_key_messages_and_findings_2014-2016_pl_0. pdf, dostęp: 26.05.2021.

Homplewicz J. (1983), Kierunki rozwoju prawa szkolnego w Polsce, [w:] J. Łętowski, J.P. Pruszyński (red.), Prawo. Administracja. Gospodarka. Księga ku czci Profesora Ludwika Bara, Wrocław, s. 119-147.

Jadach K. (2017), Odpowiedzialność prawna nauczycieli za bezpieczeństwo dziecka w placówce oświatowej - zarys problemu, Studia Prawnicze i Administracyjne, 2, s. 11-18.

Jadach K. (2020), Dyrektor szkoły w roli pracodawcy - przegląd wybranych zagadnień funkcjonowania szkoły jako zakładu pracy, Studia Edukacyjne, 57, s. 119-144.

Janiszewska-Nieścioruk Z. (2016), Rola szkoły w procesie całożyciowej edukacji osób z niepełnosprawnością intelektualną, Niepetnosprawność. Dyskursy pedagogiki specjalnej, 23, s. 103-115.

MEN 2020, Edukacja włączająca - dotychczasowe i planowane działania MEN, https://www.gov.pl/ web/edukacja-i-nauka/edukacja-wlaczajaca-dotychczasowe-i-planowane-dzialania-men, dostęp: 26.05.2021.

Mendel M., Dymnicka M., Rozmarynowska K., Sagan I., Zielka S., Puchowska M. (2008), Edukacja na rzecz zrównoważonego rozwoju, [w:] D. Klus-Stańska (red.), Dokąd zmierza polska szkoła?, Warszawa, s. 83-121.

Pentor Research International (2009), Badania wplywu kierunku i poziomu wykształcenia na aktywność zawodową osób niepetnosprawnych, raport końcowy, część 1 z 6, https://www.pfron.org.pl/ fileadmin/files/r/7777_Raport_CZESC_1z6_final.pdf, dostęp: 15.06.2021.

Pilich M. (2015), Ustawa o systemie oświaty, Warszawa.

Sipowicz K., Pietras T. (2017), Wprowadzenie do pedagogiki inkluzyjnej (właczajacej), Wrocław. 
Zalecenie Rady z dnia 22 maja 2018 r. w sprawie promowania wspólnych wartości, edukacji włączającej i europejskiego wymiaru nauczania, sygn. ST/9010/2018/INIT, https:/ec.europa.eu/ education/education-in-the-eu/council-recommendation-on-common-values-inclusive-education-and-the-european-dimension-of-teaching_pl, dostęp: 26.05.2021.

\section{Akty prawne}

Konwencja o Prawach Osób Niepełnosprawnych sporządzona w Nowym Jorku dnia 13 grudnia 2006 r., DzU z 2012 r. poz. 1169.

Rozporządzenie MENiS z dnia 31 grudnia 2002 r. w sprawie bezpieczeństwa i higieny w publicznych i niepublicznych szkołach i placówkach, DzU z 2020 r. poz. 1604.

Rozporządzenie MEN z dnia 9 sierpnia 2017 r. w sprawie warunków organizowania kształcenia, wychowania i opieki dla dzieci i młodzieży niepełnosprawnych, niedostosowanych społecznie i zagrożonych niedostosowaniem społecznym, DzU z 2020 r. poz. 1309.

Ustawa z dnia 14 grudnia 2016 r. Prawo oświatowe, DzU z 2021 r. poz. 1082. 
